\title{
Women's Stereotypes in the Novel Perempuan Bayangan: A Structural Approach Study
}

\author{
Jeprayana \\ Institut Agama Islam Negeri Bengkulu \\ Jepra.arma12@gmail.com \\ Vebbi Andra \\ Institut Agama Islam Negeri Bengkulu \\ vebbiandra@yahoo.com \\ Wenny Aulia Sari \\ Institut Agama Islam Negeri Bengkulu \\ auliasariwenny@gmail.com
}

\begin{abstract}
This research was aimed to describe the intrinsic elements and the stereotypes of women found in the main characters of the novel Perempuan Bayangan by Netty Virgiantini. This research was designed by using a qualitative approach and content analysis method. In this research, the researchers implemented documentation techniques (literature study) in collecting the data of this research. Moreover, the interactive framework was used as the data analysis technique. The result of this research revealed that the intrinsic elements found in the novel included the theme (the eternity of love), characters, and the characterization. The characters and characterization consisted of the major characters, the supporting characters, and the shadow characters. The major characters were Ningrum, Satria and Padmi. The supporting characters were Ponco, Pandu, Pratiwi, Mrs. Sinta, Kokok, Tia, Satria's mother and Ningrum's mother. The shadow character was Utari. The setting of this novel included the Satria's living room, pujahera, kitchen, boarding room, in the toast stall, restaurant, Ningrum's parents' house, office, sofa, the landlord's house. The setting of time included in the morning, evening, afternoon, and noon. The plot of the novel was chronological, and the points of views were first-person and third-person. The figure of speech included simile and oxymoron. Moreover, the moral values showed that one of the best ways in loving someone who died is by letting them go and praying for their peace in heaven, and never judge people at will by comparing them to the other ones as each person has its different strengths and weaknesses from each other. The woman's stereotype found in the novel was that marriage was just based on personal benefits. The silence of women was considered as a sign of agreement on anything. Husband compared his wife to other women, and yelled at the wife whenever she was doing something.
\end{abstract}

Keywords: Structural Approach, Perempuan Bayangan's women’ Stereotypes

\section{A. Introduction}

Literary work can be defined as a work of art made by a person or group of people in the form of beautiful writing. Writers commonly compose their stories based on stories in real life, the writers' imagination, or stories driven from the 
past. It can be used by readers to enrich their knowledge of literature, and provides moral values that can be applied in everyday life. Moreover, it has aesthetic value to make readers feel entertained while reading. Literary works that have been created based on imaginative stories can stimulate the readers to feel the events or conflicts that occur in the story itself. Thus, it is also very closely related to human life. It is able to give a moral value, imagination, and creativity from a writer. One of the popular literary genres among the society is a novel (Kutha Nyoman Ratna, 2011).

Novel refers to a fictional story whose story is written based on real stories experienced by the writers. It consists of story elements. Therefore, it is presented in detail, so it is able to include the intrinsic elements which can reveal common stereotypes towards women in a society (Hanna Rambe, 2016).

Women's stereotypes refers to positive or negative beliefs that are made by a person or group of people through unjustified negative attitudes, such as assuming that women are always dominated by men in everyday life, so women must be under the power of men and women. It is absolutely reasonable for women to determine whatever they want to do in their life, whether they are married or not. Nevertheless, in real life, women are assumed not to be able to control their own lives at all, everything is governed by men. All aspects of women's lives are determined by the political aspects of life, so that power makes men always place women under their control. In analyzing novels, researchers usually use various approaches, one of them is a structural approach (Mansour Fakih, 2015).

Structural approach is an approach that analyzes part of the structure that emphasizes the intrinsic elements of a literary work such as a novel. In addition, the structural approach has the aim of understanding carefully and exploring appropriately, in order to get good analytical results in a literary work (Ali-Imron and Al-Maruf, 2017).

\section{B. Research Method}


This research was designed by implementing qualitative research using a content analysis method (content analysis). Qualitative research is a research procedure that produces descriptive data in the form of written or spoken words from people and observable behavior. This research implemented a natural setting which was intended to interpret the existing phenomena by involving various existing methods (Sugiyono, 2017). It means that this research is aimed to understand the phenomenon of what is experienced by the research subject holistically in the form of description using words and language in a special natural context and utilizing various natural methods. Content analysis method is a method aimed to collect and analyze documents. After the researchers collected the research data related to the themes and discussions of this research, they immediately started to analyze the data. In this process, the first thing to do was to clarify the data and read repeatedly about the contents of the novel (Sugiyono, 2017).

In this research, the researchers analyzed the novel Perempuan Shadowby Netty Virgiantini with a study of structural approach. The structural approach in this research was done by analyzing the forms of women's stereotypes and the intrinsic elements of the novel. Data is the result of recording researchers in the form of words, facts, and numbers. The data in this research were the sentences contained in the novel "Perempuan Shadow" by Netty Virgiantini. The objects studied in this research were the intrinsic elements of the novel using structural studies and the women's stereotypes. Moreover, the data were collected in the form of words or quotes from the fictional novel. The data source in the research was a document in the form of a literary fiction novel "Perempuan Shadow" by Netty Virgiantini, this novel was first published in 2020 published by Gramedia Pustaka Utama (Jakarta) consisting of 212 pages and written in the genre of fiction (Moleong, 2017).

Furthermore, the data collection technique was a library technique using written sources. This technique is a technique carried out by searching, collecting, 
studying, and reading books, articles, or reports related to the subject or object of research. In line with the explanations above, the dominant procedure is in the form of data relating to expressions, actions, presentations, dialogues, monologues from the characters which contain characterizations and moral messages. Data collection techniques using library techniques were done before the data obtained in the research were described by using written sources (Didis Ariesandi, 2017).

\section{Result and Discussion}

\section{Result}

The research conducted in the novel Perempuan Bayangan by Netty Virgiantari obtained results and a discussion of the intrinsic elements and stereotypes of women in the novel.

\section{a. The Intrinsic Elements found in the novel Perempuan Bayangan by Netty Virgiantari}

Intrinsic elements in the novel Perempuan Shadow consisted of seven elements, namely theme, character and characterization, setting, plot, point of view, figure of speech and moral value.

1) Theme

The theme of the novel Perempuan Bayangan was the eternity of love, this could be seen in the following datum:

"Rasanya ia tak perna bosan beratus kali memandangi foto pengantinnya sendiri. Awalnya secara sengaja, namun sekarang menjadi semacam ritual dimana dia setiap pagi meluangkan waktu sekitar lima menit berdiri di depannya, hanya memfokuskan pandangan pada seraut wajah ayu yang seolah kembali menyapa dengan senyum dan sentuhan lembutnya. Sepulang kerja, ia akan membuka pintu dan sepasang matanya menangkap kembali raut wajah yang lembut dan ayu. Ia akan berhenti sejenak dan sekedar menyapanya, 'Utari, aku rindu” (Netty Virgiantini, 2020: 9).

Seen from the sentences above, it could be identified that Satria felt that it was a way to cure his longing for his late wife whom he loved so much, so he 
swore in front of his wife's corpse that he would not marry another woman because according to him all the love he had was only for his late wife. In this case, Netty Virgiantini inserted a great love between the opposite sex and showed that feeling would never go away under any circumstances. In an interview he admitted that there were things that had many lessons in human life in marriage behind every literary work.

\section{2) Characters and Characterization}

The characters and characterizations found in the novel included the major characters, supporting characters and shadow characters.

a) Major Characters

The major characters of the novel Perempuan Bayangan by Netty Virgiantari, Ningrum, Satria and Padmi, determined the overall development of the plot. The three figures conveyed a lot of tendencies regarding domestic life, which had only been fostered for a few months and were dominant towards the character of Ningrum. The character who was outspoken, independent, hard-working, mature, patient and had a soft and kind heart. Moreover, the major male character named Satria who had a loving, quiet, hard-working, advisory character, while the other major female character named Padmi who had temperamental character, caring, and hard working. The characters found in the novel Perempuan Bayangan could be seen from the following datum:

\section{Ningrum}

"Kesan yang didapatkan ku mengenal sosok Ningrum adalah seorang perempuan mungil, ramah, ceplas-ceplos, mandiri, pekerja keras, dewasa, penyabar dan riang dan cenderung tak peduli membuat Satria tertegun dan mulai merasa tertarik mengamatinya. Menangkap beberapa kali pandangan mata yang tertuju padanya tak tampak sorot matanya penuh kesedihan atau tatapan kosong yang biasa terjadi pada orang yang depresi” (Netty Virgiantini, 2020: 50). 
Ningrum as the main character who always did whatever she thought could make herself happy and tended not to care about things that she did not think were important to discuss so that to other people. She was always blunt to others when talking so that it made it easy for her to get along with other people.

b) Supporting Characters

The supporting characters were Ponco, Pandu, Pratiwi, Mrs. Sinta, Kokok, Tia, Satria's mother dan Ningrum's mother.

\section{Ponco}

“Lumayanlah Mas. Sejak Mas Ponco sering dinas diluar kota, pertengkaran kami semakin mereda. Males jugakan berantem lewat telepon, malah, sekarang rasanya kangen aja kalau Mas Ponco masih luar kota” (Netty Virgiantini, 2020: 28).

Poncho was regarded as a supporting role because his role was not prioritized, but without the role of Poncho, the story in the novel Perempuan Bayangan by Netty Virgiantari would feel bland. In the data above, Poncho was Padmi's husband, who was often told by Padmi to Ningrum and Satria about their fight at home. After they were in a long-distance relationship, they rarely had fight anymore as their love made them understand the feeling.

c) Shadow Character

In the novel Perempuan Bayangan, the shadow character was named Utari. She was in between every conflict that occured in the story even though her existence could not be seen by the other characters.

\section{Utari}

"Bukan untuk pertama kalinya Utari memilih berada dalam foto pengantinnya yang terpasang di dinding ruang tamu. Meskipun bisa bergerak bebas didalam rumah, bahkan bisa keluar masuk lewat pintu-pintu, sosoknya yang berupa bayangan samar selalu memilih foto pengantinnya di dinding ruang 
tamu itu ketika rumah dalam keadaan sepi. Disitulah iya selalu menunggu Satria pulang, bertapa ingin ia berada dialam yang sama dengan suaminya" (Netty Virgiantini, 2020: 11)

Based on the datum above, Utari was the shadow character in the novel. Her existence was invisible to other characters, but every sub-chapter of Utari's existence was always there because she wanted to convey something to other characters so that they knew that she was there, she really wanted to tell her husband to let her to be herself, so that she did not become the shadow woman anymore and lived where she belonged.

\section{3) Setting}

The setting of this novel included the setting of place and time. The setting of place included the Satria's living room, pujahera, kitchen, boarding room, in the toast stall, restaurant, Ningrum's parents' house, office, sofa, the landlord's house. The setting of time included in the morning, evening, afternoon, and noon.

a) Setting of Place

The setting of place of the novel Perempuan Bayangan by Netty Virgiantari included the Satria's living room, pujahera, kitchen, boarding room, in the toast stall, restaurant, Ningrum's parents' house, office, sofa, the landlord' house.

(a) Satria' Living Room

"Tak lama kemudian satria pulang, seperti biasa akan berhenti tepat di depan foto pengantin yang berada Di ruang Tamu untuk memandangnya. Tapi kali ini ada yang beda dengan tatapannya, bahkan berulang kali Satria mengerjap- ngerjapkan matanya, seolah dia menyakinkan pandangannya" (Netty Virgiantini, 2020: 13)

From the datum above, it could be seen that the living room was one of the settings in the novel Perempuan Shadow by Netty Virgiantari.

b) Setting of Time 
The setting of time found in the novel Perempuan Shadow by Netty Virgiantari included morning, evening, afternoon, and noon.

"Mungkin Malam ini akan menjadi pengalaman yang luar biasa karena untuk pertama kalinya ia harus berbagi tubuh dengan seorang laki-laki tanpa ada perasaan cinta sedikitpun di hatinya” (Netty Virgiantini, 2020: 67).

The setting of time in the novel Perempuan Bayangan happened in the evening. This could be seen in the datum 24, which occured in the evening when Ningrum was going to sleep for the first time with the man whose husband was married without love.

4) Plot

The plot in the novel Perempuan Bayangan was a chronological plot since the events were told from beginning to end in sequence. This plot was told from the past to the present in an orderly and sequential manner from the beginning of the story to the end of the story. In a story there was a beginning/event, middle/conflict and ending/climax of the story to determine the plot.

(a) Beginning/Event

At this stage, there were initial events that led the story to some conflicts. In the story of the novel Perempuan Bayangan, the beginning of the incident began when Satria made a ritual that he always looked at his wedding photo with his late wife every time he went to work, came home from work. If he was at home he would sit on the sofa in the living room to look at the photo of his late wife, as if there were no photos. it will make the peace in the living room gloomy. It can be seen in the following datum:

"Bukan untuk pertama kalinya Satria memandang foto pengantinya yang terpasang di dinding ruang tamu, yang posisinya lurus dengan pintu masuk. Foto itu sudah terpasang sejak empat tahun yang lalu dan telah menjadi bagian tak terpisahkan dari ruangan ini. Seolah, jika gak ada foto bertangkai ema situ, ruang tamu yang tidak begitu luas ini akan kehilangan aura ketenangannya”, (Netty Virgiantini, 2020: 28) 
The flow of events in this story began when the action of performing a ritual sitting on the sofa in the living room to look at his wedding photo with his late wife.started to be Satria's habit.

(b) Middle/Conflict

The conflict started when Ningrum made tea in the morning for Satria and it turned out that the tea made by Ningrum was immediately commented on by Satria because it didn't taste right on her tongue. It could be seen from the following datum:

"Yah, Mbak Utari memang sudah tau betul selera Mas Satria. Kalua aku, menekutehe! Kita kan baru tinggal serumah sehari semalam. Mbak Utari ninggalin catatan takaran gula dan the yang pas di lidah Mas Satria, nggak? Biar aku bisa belajar, kata Ningrum santai sambil duduk disamping Satria” (Netty Virgiantini, 2020: 101).

The flow of events in this story began when the action of performing a ritual sitting on the sofa in the living room to look at his wedding photo with his late wife.started to be Satria's habit.

(c) Ending/climax

At this stage, the reader began to get a conflict that had arisen in the previous stage and was continuing, the end of the story and the climax started from Satria when Satria had returned alone at home for seven days. It made him miss Ningrum in that house and every time Ningrum cried. Satria felt guilty for being too often to hurt her. It could be seen in the following datum:

"Rindu, kangen ingin bertemu. Terus terbayang wajah Ningrum, istilah apa yang tepat untuk menggambarkan perasaan Satria saat ini. Selama tujuh hari, dibenaknya disiksa rasa bersalah bercampur rindu, setiap terbayang ekspresi Ningrum saat menangis, rasa bersalah langsung menyesak dadanya. Detik berikutnya rasa itu berganti rindu yang menggedor-nggedor hati, menuntut keinginan untuk melihat, bertemu, dan memeluknya erat sampai perempuan mungil itu tidak bisa meninggalkannya” (Netty Virgiantini, 2020: 187). 
The datum showed that the conflict began in the story when Ningrum made tea for the first time for Satria instead of getting a compliment or thanks from Satria, Ningrum was commented that the tea she made was not suitable so she compared the tea made by her late wife, Ningrum clearly replied that it was her first time making tea for Satria and she didn't know the level yet. a sweetness that fits Satria's tongue.

\section{5) Point of View}

The points of views used in the novel Perempuan Bayangan by Netty Virgiantini were first-person and third-person. The main character used the first-person point of view that told the story in life or based on experience using its own words. Moreover, there were also the point of view of the first-person of the supporting characters, and the point of view of the third-person of the major characters. However, the most dominant point of view used in this story was the point of view of first-person.

\section{(a) First-Person Point of View}

The writer could be considered as the actor as she was directly involved in the story. This could be seen clearly in the following datum:

"Aku tau Mas, jangan mengira kalau aku gak tau tiap hari Mas Satria nyalahin

televisi dari malam sampai pagi biar rumah nggak terasa sepi" (Netty Virgiantini, 2020:39).

Based on the datum above, it could be seen that the point of view used in the novel was the first-person point of view using the pronoun "I" where the pronoun represented Padmi who was interrogating her cousin.

(b) Third-person point of view

"Ia seperti bisa ikut merasakan kesedihan yang kita alami disini" (Netty Virgiantini, 2020: 179).

Based on the datum, it showed that there was the third-person point of view of supporting characters. It could be seen that the pronoun "she" represented 
Utari. The pronoun showed that the novel used the third-person point of view. Utari looked sad to see the deep sadness felt by Satria.

6) Figure of speech

The figure of speech in the novel Perempuan Bayangan by Netty Virgiantini included simile and oxymoron which could be seen in the following datum:

"Utari adalah satunya cinta dalam hidupnya. Rasa cinta yang dulu begitu kuat dan menggelora, sekarang serupa fatamorgana diujung senja” (Netty Virgiantini, 2020: 202).

Based on the datum above, it showed that in the novel Perempuan Bayangan by Netty Virgiantini used simile (comparative figure of speech) and oxymoron. Simile can be defined as a figurative language that equalizes between one thing to another by using comparative words such as as, like, similar, for instance, like and so forth. Seen from the lines above, the writer showed that Satria's love for his late wife had always been an illusion, like the appearance of the evening twilight that came so beautifully and then returned slowly but only pain was left behind.

\section{7) Moral Value}

The moral values found in the novel Perempuan Bayangan by Netty Virgiantini were that one of the best ways in loving someone who died is by letting them go and praying for their peace in the heaven, and never judge people at will by comparing them to the other ones as each person has its different strengths and weaknesses from each other. The moral values found in the novel could be seen from the following datum:

“Aku nggak merasa kesepian. Utari selalu menemani. Seperti biasa kalimat itulah yang mungkin sudah ratusan kali diucapkan Satria, untuk menegaskan bahwa almarhum istrinya selalu ada dihatinya dan menemani hari-harinya" (Netty Virgiantini, 2020). 
Based on the datum shown in the novel Perempuan Bayangan by Netty Virgiantini, it could be seen that Satria had not been able to figure out the departure of his late wife, whom he loved so much, so according to him that his late wife had not been able to calm down and became the shadow living with him at home. His late wife continued to give him cues but always failed, actually Satria had felt something strange in the photo of her bride who was in the living room. When Satria saw the wedding photo, he felt a shadow was staring back at him, but unfortunately he never knew the meaning of the shadow, so he did not really pay his attention towards the situation at the time. Utari continued to try to tell the message to Satria so that she could rest in peace.

\section{b. The women's stereotype found in the novel Perempuan Bayangan by} Netty Virgiantini

The women's stereotype found in the novel Perempuan Bayangan by Netty Virgiantini were that marriage was just based on personal benefits, the silence of women was considered as a sign of agreement to anything, and the husband yelled at the wife whenever doing something.

1) Marriage was just based on personal benefits

In marriage, there should be a sense of love that grows so big that it will make the household harmonious. It is contrary to the story in the novel Perempuan Bayangan by Netty Virgiantini. It could be seen that Satria married Ningrum based on his personal benefits as he has felt lonely since his wife left him. Satria always felt lonely at home so he decided to marry the woman he did not love and care for. It was based on his intention to just find a friend to talk with to pass his boredom at home. It could be seen in the following datum:

“Aku jelaskan lagi, kenapa aku menerima rencana pernikahan ini karena pertimbangan kita berdua bisa saling melengkapi. Istilahnya, simbiosis mutualisme, hubungan yang saling menguntungkan dan saling membutuhkan" (Netty Virgiantini, 2020: 59).

2) Women's silence was considered as a sign of agreement on anything 
The woman's silence was considered a sign of agreement, although sometimes this silence was a sign of being tired of explaining to people who would not understand the meaning and purpose of what was being discussed. Thus, it was better for women to be silent. No wonder that the women's silence was considered as agreement on anything. It could be seen from the following data:

“Untuk beberapa saat Ningrum hanya memandang Satria dengan air mata terus mengalir. Ia ingin marah, ingin memaki-maki laki-laki itu tapi tak bisa, tak sanggup tidak mampu menggerakkan bibirnya. Ia hanya bisa berdiri diam. Hal yang dilakukannya adalah segera menggerakkan kaki. Melangkah meski terasa berat.berjalan menuju Satria yang berdiri didepan pintu pandangannya lurus ke depan dengan posisi kepala kaku. Raut mukanya menunjukan rasa marah dan terluka. Langkahnya mantap menuju kamar sebelah, tempat barang-barangnya disimpan." (Netty Virgiantini, 2020: 161)

Based on the datum above, it could be seen that Ningrum did not break the photo frame of the bride and groom of Satria and Utari, but Satria was angry and cursed Ningrum using harsh words, although the photo fell by itself. When Satria saw Ningrum was cleaning the scattered glass, it made Satria believe that she broke the photo. Nevertheless, she was only able to be silent.

3) Comparing wife to other woman

In the novel Perempuan Bayangan by Netty Virgiantini, it showed that the wife was compared to other women. It was reasonable as Satria had never been satisfied with whatever his wife did, so in the eyes of Satria Ningrum was always wrong and was compared to his late wife. It could be seen in the following datum:

"Tadi kurang manis ditambah gula, sekarang mala terlalu manis, kata Ningrum, Ya nambahin gula nya kebanyakan. Utari ajah bikin teh selalu pas di lidah, rasanya sepet-sepet manis, nggak perna kurang sedikit pun, jawab Satria” (Netty Virgiantini, 2020: 107).

4) Yelling at wife yelled at the wife whenever she was doing something. 
This habit of yelling at his wife owned by Satria in the novel Perempuan Bayangan by Netty Virgiantini could be seen in the following datum:

"Kamu lagi ngapain? Buat apa kamu liat foto USG itu? Kan sudah aku bilang jangan perna mengubah apapun dirumah ini! ujar Satria memperingati dengan suara yang keras yang penuh tekanan untuk menguatkan peringatannya” (Netty Virgiantini, 2020: 142).

From the datum in the novel Perempuan Bayangan by Netty Virgiantini, it could be seen that Satria yelled at his wife loudly and to warn her not to move anything in the house. He did not want any objects in the house shifted as he thought that the only memory that his wife left behind was the position of the house being neat and orderly.

\section{Discussion}

The novel Perempuan Bayangan by Netty Virgiantari was designed using a youth genre published by PT Gramedia Pustaka Umum Jakarta in 2020 and consisted of 212 pages. This novel told about the life of Satria who had been abandoned by his wife and their unborn baby. This condition made Satria felt lonely at home so one day his cousin matched her with one of her best friends named Ningrum. Finally, Satria married here without love. It made Ningrum always depressed because she was always being compared with his late wife.

Novel comes from the Italian language entitled Novella which means new and small. In its development, the novel is defined as a literary work in prose. The novel is an imaginative work that tells the whole side of the problems in someone's life. The story of the novel begins with the emergence of a problem that experienced by the characters until the completion stage. The level of depth and breadth of the story makes the difference in complexity between the settings used in the novel more of an extensive (horizontal) exploration. As the result, the novel takes a variety of places and a longer time (E. Kosasih Novel, 2008).

In general, stereotypes can be related to a form of standardizing a view of human groups by giving certain characteristics, regardless of individual abilities. 
Consolidation of views on the position of women and men against women as stereotypes is quite large (Mansuor Fakih, 2015). In fact,we can analyze that if only women and men were no longer distinguished by their gender roles, then the increase in the family's economy could be raised. We could analyze that women and men could not be distinguished because of their gender. (S. Walby, 2018).

The intrinsic element refers to the element that directly builds the literary work, which is factually contained in a literary work, it is this element that makes a work present as a literary work or from the reader's point of view, it is the story elements that will be encountered when reading a novel. The intrinsic elements are: theme, character, characterization, setting, plot, point of view, language style and moral value (Ali Imron Al-maruf, 2017).

\section{Conclusion}

Based on the results of research and discussion that have been explained above, the conclusion of this research is described as follows: (1) the intrinsic elements found in the novel included the theme (the eternity of love), characters, and the characterization. The characters and characterization consisted of the major characters, the supporting characters, and the shadow characters. The major characters were Ningrum, Satria and Padmi. The supporting characters were Ponco, Pandu, Pratiwi, Mrs. Sinta, Kokok, Tia, Satria's mother and Ningrum's mother. The shadow character was Utari. The setting of this novel included the Satria's living room, pujahera, kitchen, boarding room, in the toast stall, restaurant, Ningrum's parents' house, office, sofa, the landlord's house. The setting of time included in the morning, evening, afternoon, and noon. The plot of the novel was chronological, and the points of views were first-person and thirdperson. The figure of speech included simile and oxymoron. Moreover, the moral values showed that one of the best ways in loving someone who died is by letting them go and praying for their peace in heaven, and never judge people at will as each person has its different strengths and weaknesses from each other. (2) The 
woman's stereotype found in the novel was that marriage was just based on personal benefits. The silence of women was considered as a sign of agreement. Husband compared his wife to other women, and yelled at the wife whenever she was doing something.

\section{References}

Al Maruf dan Al Imron. (2017). Pengajian Sastra Teori dan Aplikasi. Surakarta: CV Dijawa Amarta Press.

Aminudin. (2016). Karakter Tokoh dalam Novel Langit Mekah Berkabut Merah Karya Geidurrahma Al-Misshry Berbasis Nilai-Nilai Karakter Religious dan Implikasikan dalam Pembelajaran Sastra di Madrasah Aliya. Jurnal Refleksi Edukatika, 7(1), 2.

Didis, A. (2017). Analisis Unsur Penokohan dan Pesan Moral dalam Novel Sang Pemimpi Karya Andre Hirata Sebagai Upaya Pemilihan Bahan Ajar Aprisiasi Sastra di SMA. Jurnal Pendidikan, Kebahasaan, dan Kesusastraan Indonesia, 1(1), 3-11.

Faruk. (2017). Pengantar Sosiologi Sastra dari Strukturalisme Genetik sampai Moderenisme. Yogyakarta: Pustaka Belajar

Tarigan, H.G. (2011). Prinsip-Prinsip Dasar Sastra. Jakarta: Nuansa.

Kosasih. (2008). Apresiasi Sastra Indonesia. PT Perca.

Mansour, F. (2015). Subordinasi Anak Perempuan dalam Keluarga. Jurnal Uquilibrium, 1(1), 35.

Moelong. (2013). Metodologi Penelitian Kualitatif. Jakarta: Raja Grafindo Persada.

Ruslan, R. (2013). Metode Penelitian Public Relation dan Komunikasi. Jakarta: Raja Grafindo Persada.

Rambe, H. (2016). Representasi Penindasan Ganda dalam Novel Mirah dari Banda Berdasarkan Resfektif Feminisme Poskolonial. Jurnal Poitika IV(1), 34.

Stanton, R. (2007). Teori Fiksi. Yogyakarta: Pustaka Pelajar. 
Publisher: Yayasan Karinosseff Muda Indonesia

Sugiyono. (2017). Metode Penelitian Kuantitatif, Kualitatif dan $R$ dan $D$. Bandung: Alfabeta.

Sudaryanto. (2015). Metode dan Analisis Bahasa. Yogyakarta: Sanata Dharma University Press.

Virgiantini, N. (2020). Perempuan Bayangan. Jakarta: PT Gramedia Pustaka Utama. 